\title{
HIGH ORDER THINKING PADA PEMBELAJARAN IPA MELALUI TEKNIK MAKE - A MATCH DI SEKOLAH DASAR
}

\author{
Asdiana \\ Guru Sekolah Dasar 01 Sayap \\ Asdiana@gmail.com
}

To the effect this research is subject to be know make's tech implement a. match to increase high thinking's order student on natural sciences learning about living thing fitting material. Executed research at Tana Tidung's Regency Elementary School, with subjek student research brazes 5 total one 32 students. This research constitute action research by use of model kemmis and McTaggart, one that is done in two cycles. Each cycle consisting of planning phase, performing, watch, and reflection. Process data collecting via essays high thinking's order in write, and non essays as result of tech performing observation make a. match, utilizing activity observation sheet learns and student, field note and documentation result. Result observationaling to point out marks sense peingkatan high thinking's order student on natural sciences learning, notably about living thing fitting, by applying tech make a. match. It proved by point essays high thinking's order student on i. cycle which is $56 \%$ complete student, worked up on cycle II. up to $84 \%$ complete student. Activity learns and student accord this tech steps up to $100 \%$ (mastery learning) at the early cycle II.

Key word: Make's tech a. match, high orders thinking on adjusted natural sciences learning living thing, action research.

\begin{abstract}
Abstrak: Tujuan penelitian ini adalah untuk mengetahui penerapan teknik make- a match untuk meningkatkan high order thinking siswa pada pembelajaran Ilmu Pengetahuan Alam tentang materi penyesuaian makhluk hidup.Penelitian dilaksanakan di Sekolah Dasar Kabupaten Tana Tidung, dengan subjek penelitian siswa kelas 5 yang berjumlah 32 siswa. Penelitian ini merupakan penelitian tindakan dengan menggunakan model Kemmis dan McTaggart, yang dilakukan dalam dua siklus. Masing-masing siklus terdiri dari tahap perencanaan, pelaksanaan, pengamatan, dan refleksi. Proses pengumpulan data melalui tes high order thinking secara tertulis, dan non tes berupa hasil observasi pelaksanaan teknik make- a match, menggunakan lembar observasi kegiatan guru dan siswa, catatan lapangan dan hasil dokumentasi.Hasil penelitian menunjukkan adanya peingkatan high order thinking siswa pada pembelajaran IPA, khususnya tentang penyesuaian makhluk hidup, dengan menerapkan teknik make- a match. Hal ini dibuktikan dengan nilai tes high order thinking siswa pada siklus I yaitu $56 \%$ siswa yang tuntas, meningkat pada siklus II mencapai $84 \%$ siswa yang tuntas. Kegiatan guru dan siswa sesuai langkah-langkah teknik ini mencapai 100\% (mastery learning) pada akhir siklus II.
\end{abstract}

Kata kunci: Teknik make-a match, high order thinking, natural science, penelitian tindakan. 
Era globalisasi saat ini, pemerintah sangat memperhatikan perkembangan ilmu pengetahuan dan teknologi. Hal ini terlihat dari kebijakan yang dikeluarkan oleh pemerintah tentang percepatan pembangunan nasional yaitu pembangunan di bidang pendidikan yang bertujuan untuk meningkatkan mutu SDM Indonesia di bidang IPTEK agar mampu bersaing secara global. Salah satu percepatan tersebut yaitu memberikan pembelajaran IPA di setiap jenjang pendidikan di Indonesia termasuk jenjang Sekolah Dasar. Hal ini dikarenakan pendidikan IPA pada tingkat dasar akan memberikan konstribusi yang sangat berarti bagi keseluruhan proses pendidikan siswa dan perkembangan individu selanjutnya.

Dalam perkembangan teknologi dan informasi di era sekarang, mata pelajaran Ilmu Pengetahuan Alam (IPA) di Sekolah Dasar akan memberikan kontribusi yang sangat berarti bagi peserta didik karena dalam pembelajaran IPA berhubungan dengan cara mencari tahu tentang alam secara sistematis, sehingga IPA bukan hanya penguasaan kumpulan pengetahuan yang berupa fakta-fakta, konsep-konsep, atau prinsip-prinsip saja tetapi juga merupakan suatu proses penemuan. Pembelajaran mata pelajaran IPA diharapkan dapat menjadi wahana bagi peserta didik untuk mempelajari diri sendiri dan alam sekitar, serta melihat masa depan dengan pengembangan lebih lanjut menerapkannya dalam kehidupan sehari-hari. Proses pembelajarannya menekankan pada pemberian pengalaman langsung untuk mengembangkan kompetensi agar memahami alam sekitar secara ilmiah.

IPA diperlukan dalam kehidupan sehari-hari untuk memenuhi kebutuhan manusia melalui pemecahan masalahmasalah yang dapat diidentifikasikan. Implementasi pembelajaran IPA perlu dilakukan secara bijaksana agar tidak berdampak buruk terhadap lingkungan. Di tingkat Sekolah Dasar diharapkan ada penekanan pembelajaran Salingtemas (Sains, lingkungan, teknologi, dan masyarakat) yang diarahkan pada pengalaman belajar untuk merancang dan membuat suatu karya melalui penerapan konsep IPA dan kompetensi bekerja ilmiah secara bijaksana.

Proses pembelajaran IPA akan berhasil tentunya tidak terlepas dari keberhasilan guru dalam mendidik siswa di sekolah. Maka, tidak heran guru dikatakan ujung tombak dalam pendidikan. Agar keberhasilan dalam mengajar dapat terwujud tentunya guru harus dapat mengaktifkan proses belajar siswa dan membuat proses belajar siswa menjadi efisien. Hal ini dapat dilakukan dengan 
High Order Thinking Pada Pembelajaran Asdiani

memilih teknik yang tepat untuk digunakan dalam proses pembelajaran. Sehingga diharapkan pembelajaran IPA tidak lagi monoton tetapi menjadi lebih aktif, efisien, menyenangkan dan lebih bermakna.

Setiap individu membutuhkan proses belajar untuk merubah diri seseorang. Belajar merupakan sebuah proses yang natural untuk merubah pribadi seseorang. Tentu hal ini juga yang terjadi pada siswa di sekolah. Gagne dalam Pribadi(2009), menyatakan bahwa belajar dipandang sebagai proses alami yang dapat membawa perubahan pada pengetahuan, tindakan, dan perilaku seseorang (A natural process that leads to changes in what we know, what we can do, and how we behave).

Hasil dari proses belajar siswa merupakan kemampuan-kemampuan atau kompetensi yang termuat dalam tiga ranah yaitu kognitif, afektif serta psikomotorik. Di antara ketiga ranah tersebut, penilaian hasil belajar lebih sering dilakukan pada ranah kognitif. Sebagaimana dinyatakan oleh Sudjana(2010), di antara ketiga ranah itu, ranah kognitif yang paling banyak dinilai oleh para guru di sekolah karena berkaitan dengan kemampuan para siswa dalam menguasai isi bahan pelajaran.

Dimensi kognitif dalam taxonomi Bloom oleh Anderson dan Krathwohl (2001) meliputi proses mengingat,

memahami, mengaplikasi, menganalisis serta mencipta. Proses berpikir sangat dibutuhkan dalam belajar. Proses berpikir terus menerus akan melahirkan pemikiran yang berkualitas serta menjadikan seseorang dapat berpikir tingkat tinggi atau disebut juga high order thinking(HOT). Stein dan Lane dalam Thompson (2008) HOT isthe use of complex, nonalgorithmic thinking to solve a task in which there is not a predictable, well-rehearsed approach or pathway explicitly suggested by the task, task instruction, or a worked out example".

Dalam kesempatan lain McDavitt, (1993) dalam FJ. King, dkk menyatakan higher order skills include analysis, synthesis, and evaluation and require mastery of previous levels, such as applying routine rules to familiar or novel problems.

Sejalan dengan hal tersebut dalam meningkatkan berpikir tingkat tinggi perlu ditetapkan tujuannnya. Ball \& Garton (2005) dalam Barbara. L Dkk mengatakan: The development of well-written objectives will greatly accelerate a learner's movement into higher level thinking."Artinya pengembangan tujuan yang ditulis dengan baik akan sangat mempercepat gerakan pelajar dalam berpikir tingkat tinggi. 
Aly dan Rahma(2010) mengatakan bahwa IPA adalah suatu pengetahuan yang teoritisyang diperoleh/disusun dengan cara yang khas/khusus, yaitu melakukan observasi eksperimentasi, penyimpulan, penyusunan teori, eksperimentasi, observasidan demikian seterusnyakait mengait antara cara yang satu dengan cara yang lain. Cara untuk memperoleh ilmu secara demikian ini terkenal dengan nama metode ilmiah.Sedangkan menurut Carin dan Sund(1998) IPA merupakan suatu cara untuk mengetahui tentang alam melalui kumpulan data yang diperoleh melalui pengamatan dan penelitian yang terkontrol yang didalamnya memuat proses, produk dan sikap manusia.

Agar siswa dapat berhasil dalam kemampuan berpikir tingkat tinggi atau high order thinking dalam pembelajaran IPA maka dibutuhkan keterampilan proses. Semiawan, $\operatorname{Dkk}(1998)$ yang dimulai dari kegiatan observasi sampaikan dengan mengkomunikasikan. Keterampilan proses tentu tidak semua dapat diterapkan disesuaikan dengan kemampuan dan materi yang diajarkan.

Berdasarkan pemaparan di atas maka kemampuan berpikir tingkat tinggi atau high order thinking dalam pembelajaran IPA meliputi kemampuan menganalisis dan mengevaluasi melalui ketrampilan proses.Kemampuan tersebut dapat dilihat melalui skor yang didapat oleh siswa setelah menjawab soal-soal yang dibuat oleh peneliti sebagai instrument untuk mengukur variabel high order thinking pada pembelajaran IPA tentang penyesuaian makhluk hidup. Adapun indikator yang digunakan untuk menyusun butir soal pada intrumen adalah 1) Mengamati cara hewan atau tumbuhan menyesuaikan diri dengan lingkungannya, 2) Membandingkan kekuatan jenis hewan tertentu berdasarkan bentuk kakinya, 3) Mengklasifikasikan hewan berdasarkan jenis makanannya dan hewan buas dengan hewan tidak buas, 4) Meramalkan penyebab kelangkaan hewan atau tumbuhan tertentu,

5) Mengkomunikasikan kesesuaian cara hewan atau tumbuhan menyesuaikan diri dengan lingkungannya, 6) Menyimpulkan penyebab hewan atau tumbuhan dapat bertahan hidup pada lingkungan tertentu, 7) Menerapkan pengetahuan tentang penyesuaian diri makhluk hidup (hewan dan tumbuhan) dalam kehidupan seharihari.

Penelitian ini dalam pembelajaran menggunakan metode kooperatif. Menurut Slavin (2009) mengatakan pembelajaraan kooperatif merujuk pada berbagai metode pengajaran dimana para siswa bekerja dalam kelompok-kelompok kecil untuk saling membantu satu sama lainnya dalam 
mempelajari materi pelajaran. Jelas bahwa hal ini menunjukakn segala metode pengajaran dapat memanfaatkan pembelajaran kooperatif artinya dalam kelompok dan juga dapat digunakan dalam berbagai materi pelajaran di sekolah

Suatu metode dalam pembelajaran tidak akan berrhasil bila tidak ada cara yang digunakan untuk ketercapaian metode tersebut dalam hal ini adalah teknik. Rohman dan Amri (2013) mengatakan bahwa teknik adalah cara yang dilakukan orang dalam rangka mengimplementasikan suatu metode yaitu cara yang harus dilakukan agar metode yang dilakukan berjalan efektif dan efisien.Teknik yang digunakan dalam pembelajaran ini yaitu teknik make- $a$ match.

Keunggulan dari teknik make- a match yaitu berguna untuk meningkatkan partisipasi dan keaktifan siswa dalam kelas. Hal ini dikarenakan seluruh aktifitas pembelajaran berpusat pada siswa (student centered), guru hanya sebagai motivator, maupun fasilitator.Teknik pembelajaran make a match atau mencari pasangan dikembangkan oleh Lorna Curran yang dikutip Lie (2014) yaitu Salah satu keunggulan tehnik ini adalah siswa mencari pasangan sambil belajar mengenai suatu konsep atau topik dalam suasana yang menyenangkan.
Teknik make- a match sangat sesuai digunakan dalam mengajar siswa sekolah dasar terutama siswa kelas V. Seperti diketahui bahwa usia anak sekolah dasar khususnya kelas $\mathrm{V}$ telah mencapai tahap kognitif sosial.Dikutip oleh Husamah dan Yanur (2013) dari teori Lev. S. Vygotsky mendasari pemikiran bahwa budaya berperan dalam belajar seseorang. Budaya adalah penentu perkembangan sehingga proses belajar individu dipengaruhi oleh lingkungan utama budaya keluarga.Dalam hal ini berarti pada saat belajar sesorang melakukan interaksi dengan lingkunganya, agar seseorang dapat berkembang dalam proses belajarnya. Lingkungannya dalam hal ini yaitu ligkungan sekolah, baik interaksi dengan guru maupun interaksi dengan teman-teman di kelas.

Berdasarkan penjelasan di atas, metode kooperatif dengan teknik make- $a$ match peneliti menyimpulkan yang dimaksudkan dengan teknik pembelajaran make-a match adalah sistem pembelajaran yang mengutamakan penanaman kemampuan sosial terutama kemampuan bekerjasama, kemampuan berinteraksi di samping kemampuan berpikir cepat melalui permainan yang dibantu kartu, yaitu kartu yang berisi soal atau permasalahan kartu jawaban kemudian siswa mencari pasangan kartunya. Dengan memperhatikan prinsip-prinsip dari teknik 
pembelajaran make-a match yaitu anak belajar melalui berbuat, panca indera, bahasa dan gerak.

\section{METODE}

Penelitian ini merupakan Classromm Action Research atau penelitian tindakan kelas yang dilakukan dalam bentuk siklus. Rancangan tindakan penelitian yang digunakan dalam penelitian ini adalah model Kemmis and McTaggart menggunakan sistem spiral yang dimulai dari perencanaan (planning), tindakan (acting), pengamatan (observing), refleksi (reflecting), dan dilanjutkan lagi ke perencanaan kembali (replanning) sebagai dasar untuk strategi pemecahan masalah. Hubungan antara keempat tahap dalam sistem ini dipandang sebagai satu siklus.

Kisi-kisi instrumen yang ditetapkan dalam penelitian ini, yaitu instrumen high order thinking pada pembelajaran IPA yang menggunakan data kuantitatif, sehingga data ini berupa angka yang diperoleh dari hasil pengukuran. Sedangkan data nontes berupa data observasi kegiatan guru dan siswa, berupa kalimat-kalimat atau data yang dikategorikan berdasarkan kualitas objek yang diteliti yang disebut juga dengan data kualitatif. Khusus untuk data dari lembar observasi kegiatan guru dan siswa (data kualitatif), akan diubah dalam bentuk data kuantitatif, untuk melihat persentase pencapaian tujuan pembelajaran, yaitu sampai mencapai ketuntasan belajar 100\% (mastery learning).

Setelah semua data penilaian dikumpulkan, baik data kuantitatif maupun data kualitatif, maka langkah selanjutnya adalah melakukan teknik validasi hasil penelitian. Pelaksanaan validasi hasil penelitian didasarkan pada kriteria derajat kepercayaan (credibility) dengan menggunakan teknik triangulasi. Data yang dikumpulkan kemudian . Teknik analisis data dalam penelitian ini mencakup teknik analisis kualitatif dan data kuantitatif. Setelah dilakukan analisis data pada akhir tindakan, selanjutnya peneliti menginterpretasikan hasil analisis mengenai high order thinking IPA siswa, dan proses pembelajaran dengan menggunakan teknik pembelajaran make- $a$ match.

Interpretasi hasil analisis data merupakan suatu kegiatan yang menggabungkan hasil dengan pernyataan, kriteria, atau standar tertentu untuk menemukan makna dari data yang dikumpulkan, untuk menjawab permasalahan pembelajaran mengenai high order thinking IPA siswa yang sedang diperbaiki. Apabila semua indikator yang ditetapkan dalam instrumen high order thinking IPA telah dikuasai siswa, maka dapat diinterpretasikan bahwa high order 
thinking IPA telah mengalami peningkatan. Selanjutnya apabila semua indikator yang ditetapkan dalam lembar pemantau tindakan telah mencapai $100 \%$, maka dapat diinterpretasikan bahwa proses pembelajaran telah berhasil dan tuntas (mastery learning).

\section{HASIL}

Jumlah siswa dalam penelitian ini adalah 32 orang dengan jumlah butir soal tes uraian adalah 20 soal. Aktivitas guru pada siklus I tindakan ke-1 sebesar $80 \%$ dan tindakan ke-2 sebesar 85\%. Sedangkan aktivitas siswa pada siklus I tindakan ke-1 sebesar $65 \%$, dan tindakan ke-2 sebesar $75 \%$. Presentasi nilai aktivitas guru dan siswa pada siklus I tersebut menunjukkan bahwa hasil yang dicapai belum memuaskan karena terdapat beberapa tindakan yang belum dilaksanakan oleh guru dan siswa dalam pembelajaran dengan teknik make- a match.

Berdasarkan hasil siklus 1 dapat dideskripsikan bahwa siswa yang belum tuntas mendapat nilai kurang dari 75 sebanyak 14 siswa $(43,8 \%)$. Sedangkan sebanyak 18 siswa (56,3\%) dikategorikan sudah tuntas. Data tersebut belum menunjukkan adanya peningkatan high order thinking siswa pada pembelajaran IPA tentang penyesuaian makhluk hidup, karena belum mencapai standar minimal yaitu $80 \%$ dari keseluruhan siswa belum mencapai KKM, dimana nilai rata-rata kelas hanya mencapai 69 , pembulatan dari 68,6. Gambaran secara visual khususnya berkenaan dengan nilai tes high order thinking siswa pada pembelajaran IPA tentang penyesuaian makhluk.

Analisis tindakan siklus II dilakukan sama seperti analisis data pada tindakan siklus I. Berdasarkan hasil analisis tersebut dapat disuimpulkan bahwa telah terjadi peningkatan yang signifikan. Tindakan pembelajaran yang dilakukan telah tuntas mencapai 100\% (mastery learning), dimana kelemahan- kelemahan pada siklus I sudah teratasi. Pada siklus II ini presentase nilai aktivitas guru dan siswa pada tindakan ke-2 telah mencapai 100\%.

Untuk memperoleh data high order thinking siswa pada pembelajaran IPA tentang penyesuaian makhluk hidup sebagai dampak pelaksanaan pembelajaran dengan teknik make- a match, make peneliti melaksanakan evaluasi. Nilai evaluasi tersebut setelah dioleh (terdapat pada lampiran) tertera pada tabel distribusi nilai tes high order thinking siswa pada pembelajaran IPA tentang penyesuaian makhluk hidup berikut ini:

Berdasarkan tebel di atas maka, dapat dideskripsikan bahwa siswa yang belum tuntas ada 5 orang $(15,6 \%)$ karena belum mencapai KKM. Sedangkan 
sebanyak 27 siswa $(84,4 \%)$ dikategorikan sudah tuntas. Hal ini berarti pencapaian nilai high order thinking siswa pada pembelajaran IPA tentang penyesuaian makhluk hidup dengan nilai rata-rata kelas 81 pembulatan dari 80,8 telah mencapai target (melebihi 80\% jumlah siswa yang mencapai KKM).

Untuk mendapatkan gambaran secara visual mengenai nilai tes high order thinking siswa pada pembelajaran IPA tentang penyesuaian makhluk hidup. Selain itu, perbandingan dari perolehan nilai tes high order thinking siswa pada pembelajaran IPA tentang penyesuaian makhluk hidup pada siklus I dan siklus II. Pada siklus I jumlah siswa yang mendapat nilai rendah (dibawah nilai 75) cukup banyak yaitu sebanyak 14 siswa. Selanjutnya siswa yang mendapat nilai 73 - 78 yaitu sebanyak 12 siswa. Sedangkan jumlah siswa yang mendapat nilai $79-84$ hanya 7 siswa. Selanjutnya tidak ada siswa yang memperoleh nilai 85 - 90 dan 91 96.

Sebaliknya pada siklus II, siswa yang mendapat nilai di bawah 75 turun drastis yaitu sebanyak 5 siswa, sedangkan pada nilai 73 - 78ada penurunan yaitu dari 12 siswa yang memperoleh nilai tersebut turun menjadi 11 siswa, sedangkan jumlah siswa yang mendapat nilai $79-84$ menurun menjadi 3 siswa seterusnya dapat dilihat peningkatan yang signifikan pada nilai 85 -90 dan 91 - 96 terdapat 13 siswa (bandingkan pada siklus I tidak ada siswa yang memperoleh nilai sampai 96).

\section{PEMBAHASAN}

Dari perbandingan nilai tes high order thinking siswa pada pembelajaran IPA tentang penyesuaian makhluk hidup, maka dapat dipresentasikan bahwa peningkatan telah terjadi pada setiap siklus, tetapi peningkatan yang signifikan terjadi pada siklus II. Hal ini digambarkan dari pola kenaikan nilai siswa antar siklus yang mengalami peningkatan dan saling berkorelasi.

Teknik Make - A Match menuntut siswa untuk berperan aktif/ mencari pasangan kartu dalam proses pembelajaran, sehingga pembelajaran menjadi menyenangkan.

Penggunaan teknik ini sangat bermanfaat bagi guru dalam mengembangkan pembelajaran yang inovatif, kontekstual dan terintegrasi. Pembelajaran Ilmu Pengetahuan Alam di kelas V SD, khususnya materi penyesuaian makhluk hidup, dengan mengembangkan materi yang terintegrasi menjadi salah satu cara untuk membekali mereka satu kemampuan untuk menigkatkan high order thinking mereka, sehingga siswa akan lebih mudah dalam menganalisis dan mengevaluasi pada setiap mata pelajaran pelajaran. 
High Order Thinking Pada Pembelajaran Asdiani

Penerapan teknik make - a match berdampak bagi guru dan siswa. Dengan penerapan teknik ini guru bisa mempelajari karakteristik siswa secara menyeluruh, hal ini disebabkan karena teknik ini menuntut keaktifan siswa, yang mampu mengkondisikan siswa untuk bereksplorasi sesuai dengan perkembangan siswa. Selain itu, guru bisa lebih fokus untuk berperan sebagai fasilitator yang membimbing dan mengarahkan siswa dalam proses pembelajaran, dan memotivasi guru untuk melengkapi diri dengan mengembangkan pengetahuan melalui pembelajaran yang inovatif. Sedangkan bagi siswa, teknik ini mempunyai potensi yang sangat besar untuk mengaktifkan para siswa karena situasi dalam kelas memang hidup, memberi kesempatan kepada siswa untuk menemukan sendiri pemahaman merekatentang materi yang dipelajari dengan menyenangkan.

\section{SIMPULAN}

1. Pembelajaran IPA dengan menggunakan teknik Make- A Match membuat siswa cepat memahami apa yang diajarkan guru. Mereka tidak dipaksa menghafal, tetapi secara tidak langsung mereka menganalisis dan mengevaluasi melalui kartu berpasangan. Selain itu, teknik make- $a$ matchefektif dalam meningkatkan high order thinking siswa pada pembelajaran IPA. Siswa merespon apa yang diperintahkan guru. Melalui permainan menemukan pasangan kartu, secara tidak sadar mereka belajar. Hal ini membuat kegiatan pembelajaran menjadi menyenangkan, menarik dan tidak membosankan bahkan membuat siswa dapat bekerja sama dengan baik.

2. Proses pembelajaran IPA di kelas V SD, khususnya materi Penyesuaian Makhluk Hidup dengan menggunakan teknik Make- A Match, dapat meningkatkan efesiensi pembelajaran. Berdasarkan hasil observasi aktivitas guru dan siswa, hasil catatan lapangan, hasil dokumentasi dan wawancara, maka langkah-langkah pembelajaran dengan menggunakan teknik make- a match yang diterapkan dalam proses pembelajarn terus mengalami kemajuan, sehingga pada akhir siklus II proses pembelajaran telah berhasil dan tuntas yaitu telah mencapai 100\% (mastery learning)

3. Keberhasilan pembelajaran IPA di kelas V SD, khususnya materi penyesuaian makhluk hidup, ditandai dengan peningkatan high order thinking siswa pada pembelajaran IPA. Dilihat dari hasil evaluasi siklus I dan siklus II, high order thinking siswa pada pembelajaran IPA ini terus mengalami peningkatan. 
Peningkatan yang signifikan terjadi pada siklus II, dimana nilai rata-rata kelas telah melampaui nilai KKM yaitu 80,8 $(\mathrm{KKM}=75)$, dengan jumlah siswa yang tuntas sebanyak 27 siswa $(84,4 \%$ dari jumlah keseluruhan siswa).

\section{DAFTAR RUJUKAN}

Abdulah Aly dan Eny Rahma. 2010, Ilmu Alamiah Dasar, Jakarta: Bumi Aksara,

Anderson Lorin. W. and David R. Krathwohl. 2001, A Taxonomy For Learning, Teaching, and Assessing: A revision of Bloom's Taxonomy of Education Objective, New York :Addision Wesley Longman, Inc

Carin Arthur. A. dan Robert B. Sund, 1998, Teaching science Through Discovery, Columbus, Ohio: Merril Publishing Company.

Husamah dan Yanur Satyaningrum, 2013. Desain Pembelajaran Berbasis Pencapaian Kompetensi. Malang: Prestasi Pustaka.

King FJ, Ludwika Goodson, Faranak Rohani, High Order Thinking (Definition,Teaching Strategies, Assessment), (A publication of the Educational Services Program, now known as the Center for Advancement of Learning and Assessment www.cala.fsu.edu).

Lie Anita. 2014, Cooperative Learning:Mempraktekkan

Cooperative Learning DiruangRuang Kelas, Terjemahan, Jakarta: Gramedia.

L. Barbara \& Wendi. W, Developing higher level thinking Chadron State College: Journal of Instructional Pedagogies.
Pribadi dan Benny. 2009, Model Desain Sistem Pembelajaran, Jakarta: Dian Rakyat.

Rohman Muhammad dan Sofan Amri. 2013 Strategi dan Desain Pengembangan Sistem Pembelajaran. Jakarta: Prestasi Pustaka.

Slavin Robert E. 2013, Cooperative Learning:Teori,Riset dan Praktik, Bandung: Nusa Media.

Sudjana Nana. 2005, Penilaian Hasil Proses Belajar Mengajar Bandung: PT Remaja Rosdakarya

Thompson, Tony. 2008." Mathematics Teachers, Interpretation Of Higher-Order Thinking In Blomm's Taxonomy. (International Electronic Journal of Mathematics Education Vol.3 No. 2 July 2008).

]

Wiriaatmadja Rochiati, 2012. Metode Penelitian Tindakan Kelas, (Bandung: Remaja Rosdakarya. 